\title{
Elżbieta Szafranko
}

Uniwersytet Warmińsko-Mazurski w Olsztynie

e-mail: elasz@uwm.edu.pl

\section{OCHRONA ŚRODOWISKA WODNEGO A INWESTYCJE} DROGOWE

\section{PROTECTION OF THE AQUATIC ENVIRONMENT VERSUS ROAD PROJECTS}

DOI: $10.15611 / \mathrm{pn} .2017 .470 .09$

JEL Classification: L91, Q56

Streszczenie: Realizując inwestycje drogowe, niejednokrotnie przecinamy tereny cenne przyrodniczo. Wśród różnych związków ze środowiskiem jednym z ważniejszych jest interakcja tych obiektów ze środowiskiem wodnym. Przepisy regulują postępowanie tak, aby w maksymalnie zmniejszyć negatywne oddziaływania inwestycji na środowisko wodne. W wyniku analizy materiałów źródłowych sformułowano cel badań. Było nim wskazanie najważniejszych przepisów i dokumentów regulujących wpływy inwestycji drogowych na środowisko wodne. Szczegółowym badaniom poddano realizacje procesów budowy obiektu mostowego, sytemu odprowadzania ścieków z obiektu mostowego i przebudowę fragmentu drogi wraz z wykonaniem odwodnienia. W wyniku przeprowadzonej analizy stwierdzono, że bardzo dużo uwagi poświęcono właściwemu odprowadzaniu wód z nawierzchni drogowych tak, aby zminimalizować zagrożenie dla wód powierzchniowych i gruntowych ze strony zanieczyszczeń spływających z nawierzchni dróg i mostów.

Słowa kluczowe: inwestycje drogowe, ochrona środowiska wodnego, pozwolenie wodnoprawne.

Summary: In carrying out road projects we often cross valuable natural areas and the execution of works and subsequent operation of these facilities is not without significance for maintaining environmental balance. The set the goals of the research which consisted in an analysis of the rules governing the influence of road projects on the aquatic environment. A group of work related to the implementation of road projects that required water permit was determined. The specific research projects were subjected to the processes of building a bridge structure, system of sewage disposal facility and bridge reconstruction portion of the road with the complex of dehydration. Owing to the analysis it has been found that a very large emphasis is placed on proper disposal of water from the road surface. This is due to a big risk to the surface and groundwater from pollution water flowing from roads and bridges.

Keywords: road projects, protection of the aquatic environment, water permit. 


\section{Wstęp}

Rozwój dróg przynosi wiele korzyści ekonomiczno-społecznych, m.in.: zmniejszenie czasu podróży, poprawę bezpieczeństwa ruchu, podwyższenie komfortu jazdy oraz możliwość rozwoju gospodarczego kraju. Intensywny postęp jest obecnie bardzo istotny dla większości społeczeństwa, jednak napotyka on liczne przeszkody [Szafranko 2013]. Proces realizacji inwestycji drogowych często jest utrudniony ze względu na uwarunkowania środowiskowe [Bęben 2009]. Planowanie lokalizacji dróg jest dosyć kłopotliwe, ponieważ w wielu miejscach koliduje $\mathrm{z}$ wodami powierzchniowymi. Cieki i zbiorniki wodne, zabagnione doliny rzeczne, wąwozy to największe utrudnienia ze strony środowiska, jakie drogownictwo musi pokonać. Wynika z nich konieczność wykonania takich obiektów inżynierskich, jak mosty, przepusty, wiadukty oraz estakady. $Z$ kolei wykonywanie wykopów pod budowę dróg wpływa na poziom wód gruntowych, a odprowadzanie wód opadowych z ich szczelnych powierzchni wpływa na jakość zasobów wodnych [Kot 2012]. Problemy te występują od lat $\mathrm{w}$ działalności inwestycyjno-budowanej i przyczyniły się do powstania przepisów regulujących postępowanie w procesie przygotowania inwestycji związanych z rozbudową infrastruktury transportowej. Celem przeprowadzonych badań było wskazanie najważniejszych przepisów i dokumentów regulujących wpływy inwestycji drogowych na środowisko wodne oraz wytycznych zawartych $\mathrm{w}$ tych dokumentach. Analizę przeprowadzono w oparciu o dokumentację przykładowych inwestycji polegających na budowie obiektu mostowego, sytemu odprowadzania ścieków z obiektu mostowego i przebudowie fragmentu drogi wraz z wykonaniem odwodnienia.

\section{Charakterystyka wymogów prawnych związanych z ochroną przyrody i wód w procesie budowy dróg}

Podstawowym aktem prawnym regulującym działalność budowlaną jest ustawa Prawo budowlane [Ustawa z dnia 7 lipca 1994 r. ...]. Według tej ustawy każdy obiekt budowlany (a zatem także droga zaliczana do obiektów liniowych) powinien być realizowany z uwzględnieniem nie tylko przepisów technicznych dotyczących bezpieczeństwa konstrukcji i jej użytkowania, ale także zgodnie z wymogami ochrony środowiska. Dlatego, aby otrzymać pozwolenie na budowę, projekt powinien spełniać wymogi zawarte w decyzji o warunkach zabudowy i zagospodarowania terenu oraz w decyzji o środowiskowych uwarunkowaniach. W przypadku dróg projekt powinien także zawierać informacje dotyczące sposobu odprowadzania lub oczyszczania wód opadowych.

Kolejną ustawą związaną z inwestycjami drogowymi jest ustawa o drogach publicznych [Ustawa z dnia 21 marca 1985 r. ...]. W ustawie tej stwierdza się, że drogą jest budowla, której charakterystyczną cechą jest długość, dlatego zalicza się ją do 
obiektów liniowych. Na swojej długości musi ona posiadać drogowe obiekty inżynierskie pozwalające na zachowanie jej ciągłości w miejscach trudnych ze względu na uwarunkowania środowiska naturalnego. Takimi obiektami inżynierskimi są obiekty mostowe, wiadukty, estakady, tunele oraz przepusty.

Zgodnie z Rozporządzeniem Ministra Transportu i Gospodarki Morskiej (RMTiGM) w sprawie warunków technicznych, jakim powinny odpowiadać drogi publiczne i ich usytuowanie [Rozporządzenie Ministra Transportu i Gospodarki Morskiej z dnia 30 maja 2000 r. ... ], każda droga powinna mieć urządzenia odwadniające oraz odprowadzające wodę. Są one niezbędne do odprowadzania wód opadowych i roztopowych z powierzchni dróg oraz do obniżania poziomu wód gruntowych w sytuacjach, gdy są one zagrożeniem dla konstrukcji nawierzchni drogi [Sandecki 2002]. Do grupy tych urządzeń zalicza się m.in. rowy, dreny, kanalizację deszczową. Rozporządzenie szczegółowo określa parametry, jakimi należy się kierować przy projektowaniu wymienionego wyposażenia dróg.

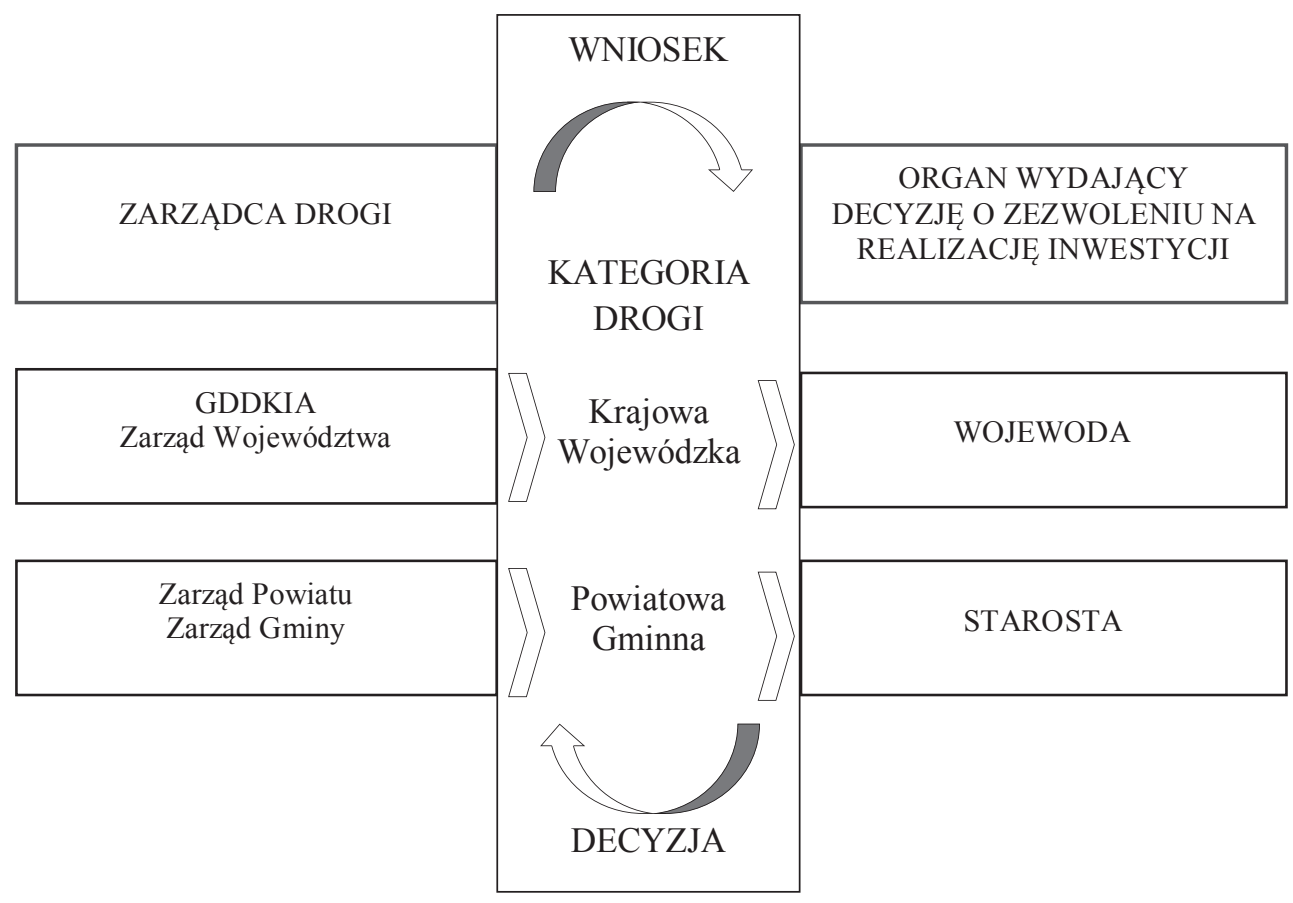

Rys. 1. Proces ubiegania się o wydanie decyzji zezwolenia na realizację inwestycji Źródło: opracowanie własne na podstawie [Ustawa z dnia 10 kwietnia 2003 r. ...].

Oprócz wymienionych warunków, projektując i wykonując drogę, należy dążyć do tego, aby nie powodowała ona zagrożenia dla wód podziemnych oraz nie pogarszała stanu odbiornika [Rozporządzenie Ministra Transportu i Gospodarki 
Morskiej z dnia 2 marca 1999 r. ...]. W związku z tym należy uwzględniać warunki hydrogeologiczne panujące w jej bezpośredniej okolicy. Nie powinno się pozwalać na niekontrolowane spływy z powierzchni dróg, które doprowadziłyby do zanieczyszczenia wód gruntowych oraz powierzchniowych. W tym celu ważna jest kontrola emisji zanieczyszczeń do środowiska oraz niwelacja ich poprzez zastosowanie urządzeń ochrony, którymi w odniesieniu do dróg są separatory, oczyszczalniki i oczyszczalnie wód. Proces ochrony środowiska wodnego powinien się opierać na przepisach zawartych w prawie wodnym.

Kolejny przepis regulujący działalność inwestycyjną związaną z budową dróg to ustawa zwana popularnie specustawą [Ustawa z dnia 10 kwietnia 2003 r. ...], określająca warunki i zasady przygotowania inwestycji drogowych w zakresie publicznym. Jej głównym założeniem jest uproszczenie i usprawnienie procedury administracyjnej związanej z rozpoczęciem procesu inwestycyjnego wszystkich kategorii dróg publicznych. W myśl tej ustawy jedynym aktem prawnym, który pozwala na rozpoczęcie robót budowlanych w procesie inwestycyjnym, jest decyzja o zezwoleniu na realizację inwestycji drogowej [Szafranko 2010]. Proces składania wniosku oraz wydawania decyzji przedstawiono w skrócie na rys. 1.

\section{Przepisy związane z zarządzaniem wodami istotne dla projektowania inwestycji drogowych}

Jedną $\mathrm{z}$ podstawowych dyrektyw $\mathrm{w}$ dziedzinie ochrony wód jest dyrektywa 2000/60/WE Parlamentu Europejskiego i Rady Europy z dnia 23 października 2000 r. ustanawiająca ramy wspólnotowego działania w dziedzinie polityki wodnej. Zgodnie z nią państwa członkowskie powinny dążyć do osiągnięcia celu, jakim jest co najmniej dobry stan wód. Można to uczynić poprzez określenie i wdrożenie koniecznych działań w ramach zintegrowanych programów, uwzględniając istniejące wspólnotowe wymogi. Tam, gdzie aktualny stan wód jest dobry, powinien on zostać utrzymany. Dodatkowo w stosunku do wymogów dobrego stanu dla wód podziemnych każda tendencja do znacznego i trwałego wzrostu stężenia zanieczyszczenia powinna zostać zidentyfikowana i odwrócona [Dyrektywa 2000/60/WE Parlamentu Europejskiego i Rady z dnia 23 października 2000 r. ...]. Wymienione obowiązki przyczyniły się do powstania licznych ustaw regulujących działalność ludzką wprowadzającą zmiany w otoczeniu.

Ustawa Prawo ochrony środowiska (POŚ) [Ustawa z dnia 27 kwietnia 2001 r. ... ] jest podstawową ustawą w dziedzinie ekologii. Określa ogół obowiązków zapewniających ochronę środowiska w procesie inwestycyjnym, m.in.: zasady ustalania warunków ochrony zasobów przyrodniczych, warunków emisji substancji oraz koszty związane z użytkowaniem środowiska, prawa społeczeństwa do udziału w procesie ochrony środowiska, zakres obowiązków jednostek administracyjnych oraz odpowiedzialność i kary wynikające z nieprzestrzegania ustalonych reguł. Według tej 
ustawy inwestor realizujący przedsięwzięcie jest zobowiązany $\mathrm{w}$ trakcie prac budowlanych uwzględnić ochronę środowiska w obrębie terenu, na którym prowadzone są prace. Dokładniejsze informacje o sposobach ochrony zasobów środowiska są wymienione w licznych ustawach oraz przepisach szczegółowych.

Ustawa Prawo wodne [Ustawa z dnia 18 lipca 2001 r. ...] reguluje wpływ działalności ludzkiej na stan wód. Naczelną zasadą jest tu gospodarowanie wodami przez zachowanie zrównoważonego rozwoju uwzględniającego regulowanie warunków korzystania z wód, ich ochronę oraz zarządzanie nimi. Instrumentami zarządzania zasobami wodnymi są: plany gospodarki wodnej, pozwolenia wodnoprawne, opłaty i należności w gospodarce wodnej, kataster wodny oraz kontrola gospodarowania wodami. Istotnym problemem związanym $\mathrm{z}$ zachowaniem $\mathrm{w}$ nienaruszonym stanie zasobów wodnych jest ich zanieczyszczenie. Zanieczyszczenia wody substancjami szkodliwymi pochodzą głównie ze ścieków. W przypadku dróg są to wody pochodzące z opadów i roztopów. Prawo wodne zabrania wprowadzania ich bezpośrednio do wód podziemnych, powierzchniowych oraz ziemi, jeśli nie są oczyszczone do takiego stopnia, jak przyjęto w przepisach ustawy. Oczyszczanie powinno odbywać się w specjalnie wybudowanych do tego celu urządzeniach, aby zminimalizować ich negatywny wpływ na środowisko wodne. Organ wydający pozwolenia wodnoprawne może określić w pozwoleniu próg ilości wprowadzanych zanieczyszczeń do wód lub do ziemi. W przypadku terenów ochrony ujęć wód, ścieki należy odprowadzać w taki sposób, aby nie przedostały się do urządzeń pobierających wodę. Istnieje także możliwość zabronienia lub ograniczenia wprowadzania robót, które mogą negatywnie wpłynąć na przydatność ujmowanej wody. Prawo wodne zalicza do nich budowę dróg [Koza (red.) 2002].

Prawo wodne zawiera klasyfikację obiektów, które zalicza się do urządzeń wodnych. W zakresie inwestycji drogowych są to rowy oraz wyloty systemu kanalizacji wyprowadzające ścieki do wód. Choć zgodnie z tą klasyfikacją most nie jest zaliczany do urządzeń wodnych, to przepisy ustawy odnoszące się do nich obowiązują także obiekty mostowe. Ponadto przepisy dotyczące urządzeń wodnych stosuje się do obiektów budowlanych, a także robót, które są wykonywane na obszarach zagrożenia powodzią oraz robót w wodach i nie tylko, które mogą przyczyniać się do zmiany naturalnego przepływu wód i ich stanu. Wymienione przypadki wynikają $\mathrm{z}$ lokalizacji, jaką jest koryto rzeki i tereny zalewowe. Tereny te mają duże znaczenie dla środowiska, dlatego wykonanie wszelkich prac, urządzeń i obiektów wpływających na nie musi być poparte wydaniem pozwoleń wodnoprawnych.

Zgodnie z wzajemnie uzupełniającymi się przepisami Prawa ochrony środowiska i Prawa wodnego przedsięwzięcia polegające na znaczącej ingerencji w środowisko wodne wymagają uzyskania decyzji określających zakres i warunki korzystania z niego. Podstawową decyzją jest pozwolenie wodnoprawne. Prace wchodzące w skład inwestycji drogowych oraz zjawiska z nimi związane, które wymagają wydania tego pozwolenia, przedstawia rys. 2 . 


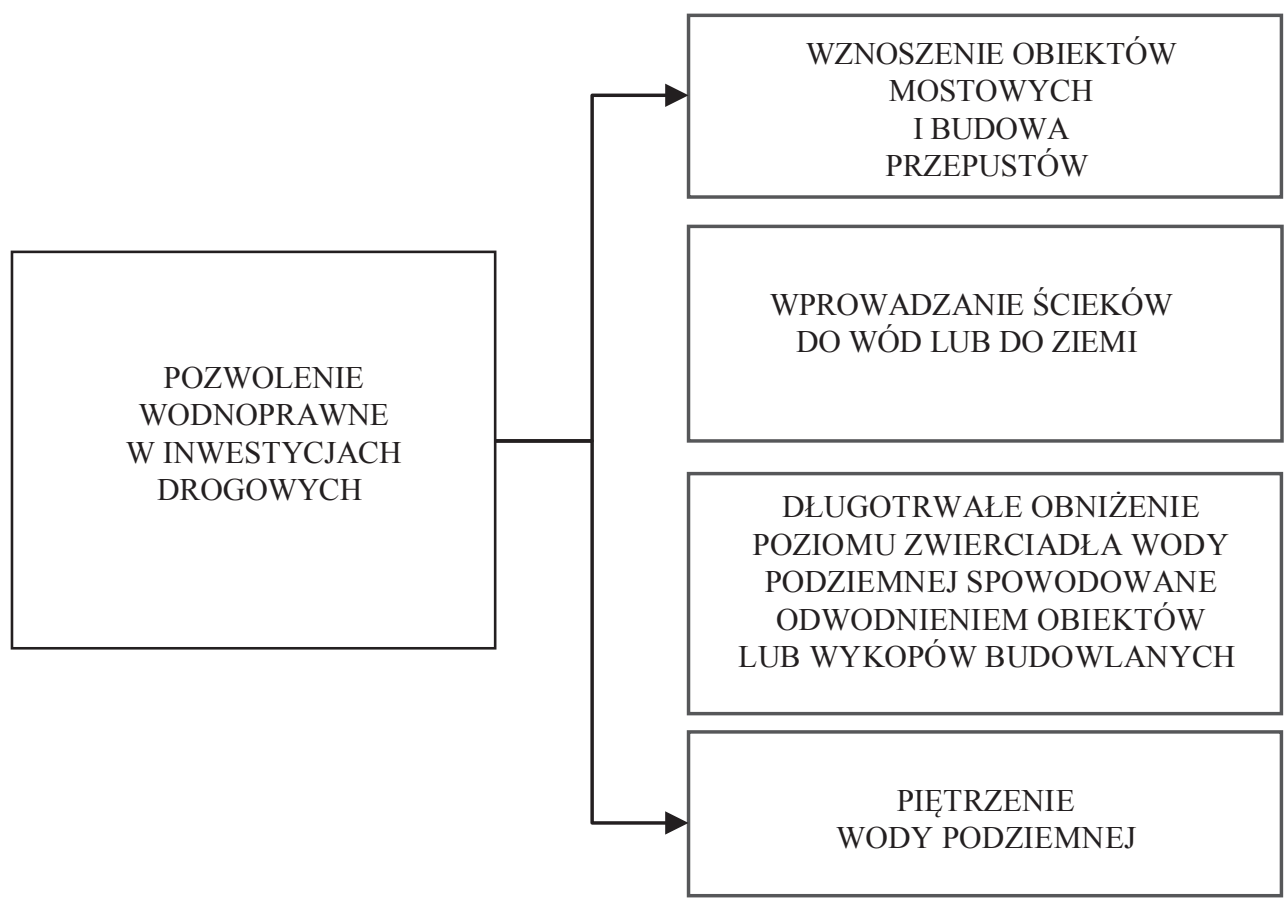

Rys. 2. Prace wymagające uzyskania pozwolenia wodnoprawnego w inwestycjach drogowych Źródło: opracowanie własne na podstawie [Ustawa z dnia 18 lipca 2001 r. ...].

Wznoszenie obiektów mostowych i budowa przepustów jest niezbędna w zachowaniu ciągłości dróg. Wymienione obiekty są trwałe i wymagają szczególnych rozwiązań technicznych, przez co mogą negatywnie wpływać na obszar wód płynących i koryta rzek. Inwestycje drogowe mogą znacząco wpłynąć na stan zanieczyszczenia wód głównie przez przenikanie ścieków opadowych i roztopowych do środowiska. Mieszanina substancji ropopochodnych i innych związków chemicznych z wodą spływającą z powierzchni drogi stanowi zagrożenie zwłaszcza dla otocznia tras o dużym obciążeniu ruchem. Obniżenia poziomu zwierciadła wody podziemnej może wymagać sytuacja, w której doszło do przerwania warstwy wodonośnej w trakcie budowy. Podniesiony poziom wody podziemnej, sięgający podstaw obiektu budowlanego, może powodować szkody i zagrażać jego prawidłowemu funkcjonowaniu. W takich sytuacjach należy zastosować system drenaży i studni, który utrzyma wymagany poziom wód podziemnych. Woda pochodząca z odwadniania najczęściej odprowadzana jest do wód płynących. Często bywa także, że w trakcie wykonywania prac w gruncie może dojść do spiętrzenia wody podziemnej. Dzieje się tak w przypadku wykonania ścianek szczelnych (ogradzających wykopy), które mają chronić przed napływem wody i umożliwić wykonanie elementu obiektu. 
Woda pochodząca z przeciętych warstw wodonośnych zostaje zatrzymana po zewnętrznej stronie ścianki, a wtedy jej poziom zaczyna się podnosić. Zarówno obniżenie poziomu wód podziemnych, jak i ich spiętrzenie może zajść w trakcie tych samych prac ziemnych, dlatego zjawiska te powinny być ujęte jednocześnie w jednym pozwoleniu wodnoprawnym. W związku ze znaczącą ingerencją wymienionych prac w poziom i stan wód wydanie pozwolenia wodnoprawnego jest niezbędne w każdym przypadku [Ociepa 2011; Edel 2010].

\section{Organy wydające decyzję}

Organem upoważnionym do wydania pozwolenia wodnoprawnego jest starosta, marszałek województwa bądź dyrektor regionalnego zarządu gospodarki wodnej, zależnie od rodzaju inwestycji i jej lokalizacji. Marszałek województwa jest odpowiedzialny za wydanie pozwolenia w kilku określonych sytuacjach. Jedną z nich jest korzystanie $z$ wód, budowa i eksploatacja urządzeń wodnych lub instalacji związana z przedsięwzięciami mogącymi oddziaływać w znacznym stopniu na środowisko i dla których należy sporządzić raport o oddziaływaniu na nie zgodnie z przepisami ustawy POŚ na terenach przemysłowych i poza nimi. Wydawanie pozwolenia na korzystanie $\mathrm{z}$ wód oraz wykonywanie urządzeń w sztucznych zbiornika zlokalizowanych na wodach płynących, które mogą zawsze istotnie wpływać na środowisko, także należy do obowiązków marszałka.

Pozostałe przypadki, w których marszałek województwa podejmuje się wydania pozwolenia, to: wznoszenie budowli przeciwpowodziowych, przerzuty wody i związana z tym budowa odpowiednich urządzeń, wprowadzanie substancji hamujących rozwój glonów do wód powierzchniowych, wydobywanie kruszyw z wód powierzchniowych bądź obszarów bezpośredniego zagrożenia powodzią i składowanie ich na tym obszarze, wznoszenie budowli i wykonywanie robót z tym związanych, wprowadzanie do systemu kanalizacji ścieków przemysłowych zawierających substancje zagrażające środowisku, wspólne korzystanie z wód (w przedstawionym zakresie oraz w przypadku wprowadzania ścieków opadowych i roztopowych, wód z przelewów kanalizacji deszczowej i wód chłodniczych do ziemi lub wód powierzchniowych w odległości nie większej niż $1 \mathrm{~km}$ od kąpielisk i plaż publicznych).

Jak łatwo zauważyć, część z tych decyzji dotyczy działań związanych z budową i eksploatacją obiektów infrastruktury drogowej. Inne sprawy związane z procesem inwestycyjnym wymagające wydania pozwolenia wodnoprawnego są kierowane do starosty, jednakże pod warunkiem że nie dotyczą terenów zamkniętych. Gdy szczególne korzystanie z wód ma miejsce w części bądź całości na terenach zamkniętych, wydawaniem pozwolenia zajmuje się dyrektor regionalnego zarządu gospodarki wodnej.

Procedura związana $\mathrm{z}$ wydaniem pozwolenia wodnoprawnego rozpoczyna się złożeniem wniosku wraz z niezbędną dokumentacją. Organ przyjmujący wniosek 
zobowiązany jest do publicznego zawiadomienia o wszczęciu postępowania. Okres, na jaki zostaje wydane pozwolenie, zależy od rodzaju wnioskowanego przedsięwzięcia. Przykładowo pozwolenie na szczególne korzystanie z wód może mieć termin ważności nie dłuższy niż 20 lat, a na wprowadzenie ścieków do ziemi lub do wód - maksymalnie 10 lat. Każde wydane pozwolenie może wygasnąć, a także zostać ograniczone lub cofnięte przez organ je wydający. Postępowanie może trwać od jednego miesiąca do dwóch, jeżeli jest to szczególnie skomplikowany przypadek. Schemat postępowania w przypadku ubiegania się o wydanie pozwolenia wodnoprawnego przedstawia rys. 3 .

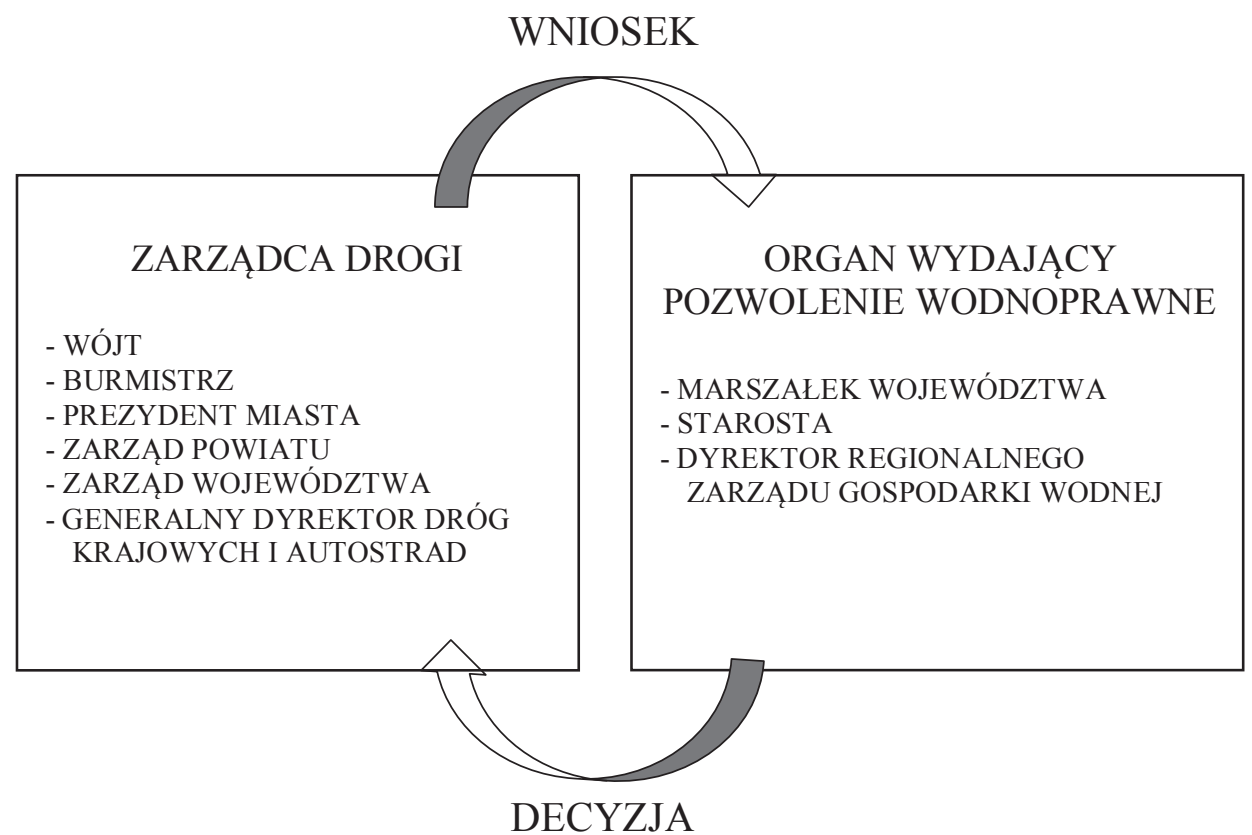

Rys. 3. Postępowanie w sprawie wydania pozwolenia wodnoprawnego

Źródło: opracowanie własne na podstawie [Ustawa z dnia 18 lipca 2001 r. ...].

\section{Opis zależności i powiązań między inwestycjami drogowymi a obiektami wodnymi}

Inwestycje drogowe ze względu na to, że ich charakterystyczną cechą jest długość, ciężko zlokalizować tak, aby nie wpływały na środowisko wodne [Bęben 2009]. Drogi mogą nie tylko przecinać cieki wodne, ale także wpływać na jakość wód po- 
wierzchniowych i podziemnych oraz na zmiany ich poziomu. Oddziaływania te można podzielić na wiele kategorii, m.in.:

- ze względu na źródło: bezpośrednie (zanieczyszczenie wód ściekami opadowymi) i pośrednie (spadek zdolności produkcyjnych gleby w pobliżu drogi),

- ze względu na częstotliwość oddziaływania: okresowe (czas budowy, przebudowy, remontu) - sezonowe (zanieczyszczenie związkami chemicznymi pochodzącymi z zimowego utrzymania dróg) - stałe (wynikające z eksploatacji drogi). Każde z tych oddziaływań powinno być uwzględnione już na etapie planowania przebiegu drogi, aby móc zminimalizować negatywny wpływ inwestycji na otoczenie [Szafranko 2013].

Projektując przebieg drogi w terenie, warto zwrócić uwagę, czy nie będzie ona zlokalizowana na obszarze torfowisk, namułów bądź innych silnie nawodnionych gruntów charakteryzujących się dużą niestabilnością. Omijanie takich terenów przynosi wiele korzyści [Kot 2012]. Przede wszystkim posadowienie jakichkolwiek budowli na takim podłożu stanowi duże zagrożenie dla stabilności ich konstrukcji. Pomijając jednak aspekty techniczne, należy zwrócić uwagę na wpływ wszelkich prac związanych z inwestycją drogową na środowisko wodne. Osuszanie, odwadnianie systemem drenażu oraz inne prace dostosowujące podłoże do wykonania konstrukcji drogi zaburzają gospodarkę wodną terenów podmokłych. Zmniejszanie zasobów wodnych pociąga za sobą negatywne skutki dla przyrody i społeczeństwa. Unikatowa dla mokradeł roślinność i zwierzęta w wyniku spadku poziomu nawodnienia giną, a strefy buforowe ekosystemów nadrzecznych, które są naturalną barierą ochronną przed dostawaniem się zanieczyszczeń do rzek, maleją. Poziom wód płynących i stojących także ulega zmniejszeniu. W przypadku naturalnych zbiorników wodnych, takich jak śródleśne oczka, dochodzi do ich zanikania.

W środowisku naturalnym (łąki, lasy, pola) wody opadowe pojawiające się na powierzchni podłoża są odprowadzane samoistnie. Po części spływają grawitacyjnie do pobliskich cieków wodnych, wsiąkają w glebę oraz odparowują. W przypadku dróg nie jest to możliwe. Popularnie stosowane bitumiczne i betonowe nawierzchnie dróg stanowią szczelną powłokę uniemożliwiającą wsiąkanie wody prosto do gruntu. W związku z tym należy zadbać o to, aby pojawiająca się na drogach woda opadowa i roztopowa została usunięta $z$ jej powierzchni za pomocą systemu odwodnienia. Do odwodnienia dróg stosuje się system otwartego odprowadzania wód, np. rowy przydrożne lub zamknięty system kanalizacyjny. Wybór najbardziej odpowiedniego systemu odwodnienia jest zależny od lokalizacji drogi oraz od szerokości pasa drogowego. Dobór odpowiedniego odwodnienia jest także zależny od jakości ścieków drogowych [Wiśniowska-Kielian, Niemiec, Arasimowicz 2013]. Te pochodzące z dróg o dużym natężeniu ruchu mogą zawierać znaczne ilości związków metali i substancji ropopochodnych, których obecność w środowisku wodnym stanowi zagrożenie dla reszty środowiska. Dlatego odprowadzenie ich wymaga specjalnego rozwiązania redukującego wprowadzanie niepożądanych substancji do wód powierzchniowych i podziemnych [Ociepa 2011]. 
Zagrożenie dla odbiorników wodnych stanowią także niekontrolowane spływy pochodzące z pasa drogowego podczas wykonywania robót ziemnych. Mogą się one przyczynić do powstania procesów erozyjnych w otoczeniu budowanej drogi oraz zanieczyszczenia gleb sąsiadujących gruntów poprzez pokrycie ich naniesionym rozmytym materiałem ziemnym. Istnieje też prawdopodobieństwo skażenia wód i gruntu lepiszczami składowanymi lub transportowanymi na obszarze prac budowlanych. Szczególną ostrożność należy zachować w pobliżu strefy ujęć wody [Bęben 2009].

Według obowiązujących przepisów wody opadowe i roztopowe pochodzące z dróg krajowych, wojewódzkich i powiatowych klasy G, które zostały ujęte w systemy kanalizacyjne i wprowadzane do wód bądź do ziemi, nie mogą zawierać więcej niż $100 \mathrm{mg} / \mathrm{dm} 3$ zawiesin ogólnych i $15 \mathrm{mg} / \mathrm{dm} 3$ substancji ropopochodnych [Wiśniowska-Kielian, Niemiec, Arasimowicz 2013]. W pozostałych przypadkach (gdy nie przekraczają wartości granicznych) wody te mogą być wprowadzane do środowiska bez wcześniejszego oczyszczania.

Zachowanie ciągłości sieci komunikacyjnych wiąże się z przeprawami przez rzeki i inne cieki wodne. Wymaga to budowy drogowych obiektów inżynierskich, takich jak mosty i przepusty. Projektując je, nie tylko należy wziąć pod uwagę aspekt wykonania stabilnej i bezpiecznej dla użytkowników konstrukcji, ale także zachować umiar w ingerencji w obszar wód płynących [Sandecki 2002]. Istotą dobrze zaprojektowanego mostu, zarówno stałego jak i tymczasowego, jest zapewnienie warunków przepływu wody w stopniu jak najbardziej zbliżonym do naturalnego. Dlatego należy zwrócić szczególną uwagę na: światło mostu, wysokość położenia spodu konstrukcji mostu ponad powierzchnią wody, dostosowanie płaszczyzn bocznych filarów podpierających konstrukcję do kierunku przepływu wody, prawidłowe wykonanie podpór technologicznych w obrębie koryta rzeki oraz sposób umocnienia jego dna. Chcąc zaprojektować most w taki sposób, aby nie był on przeszkodą dla rzeki, warto zwrócić uwagę na jego filary i podpory technologiczne. W przypadku filarów istotny jest kształt ich powierzchni bocznej. Powinna ona być ukształtowana odpowiednio do kierunku przepływu wody [Sandecki 2002].

\section{Analiza wybranych obiektów}

W celu zilustrowania tematyki przeanalizowano kilka inwestycji, które były realizowane w ostatnich kilku latach na obszarze północno-wschodniej Polski. Dobierając inwestycje uwzględniono przede wszystkim różnorodność obiektów i problemów związanych z ich budową oraz sposoby ich rozwiązywania. Do analizy porównawczej wybrano takie obiekty, jak:

- przebudowa przeprawy mostowej,

- realizacja systemu odprowadzenia ścieków drogowych z mostu,

- przebudowa drogi wraz z wykonaniem systemu drenażu. 
Analizę studialną przeprowadzono w oparciu o dokumentację udostępnioną przez zarządców dróg. Każdy z wymienionych przypadków przedstawia inne rozwiązania i problemy. Analiza opiera się głównie na operatach wodnoprawnych dołączanych przez inwestorów do wniosków o udzielenie pozwolenia wodnoprawnego i na wspomnianych pozwoleniach wystawianych przez starostwo powiatowe. Badaniom poddano wytyczne dotyczące ochrony środowiska wodnego.

Inwestycja 1 polega na budowie przeprawy przez ciek wodny wraz dojazdami. Jednym z wymogów w procesie przygotowania tej inwestycji było złożenie wniosku do starostwa powiatowego w celu uzyskania pozwolenia wodnoprawnego. Najważniejszym załącznikiem stanowiącym źródło informacji oraz podstawę do rozpatrzenia wniosku przez starostwo jest operat wodnoprawny. Został on wykonany na podstawie danych inwentaryzacyjnych istniejącego mostu oraz wyciągu z dokumentacji technicznej. W odpowiedzi inwestor otrzymał decyzję wraz z wytycznymi związanymi z ochroną środowiska. Zasadność wytycznych pokazanych na rys. 4 można zinterpretować na podstawie opisu zależności i powiązań między inwestycjami drogowymi a obiektami wodnymi.

Wytyczne związane z ochroną środowiska wodnego

Wykonanie zabezpieczeń brzegów rzeki materacami brzegowymi na długości 40 m od mostu w górę i w dół rzeki, a skarpy stożków dyblami betonowymi
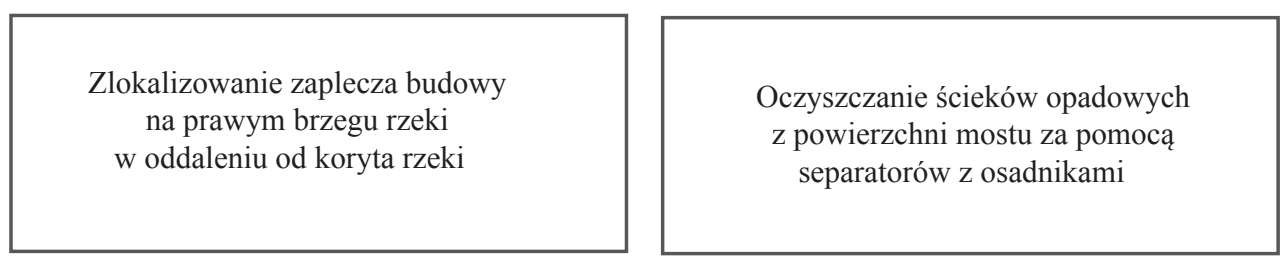

Uporządkowanie terenu po zakończeniu prac budowlanych oraz przywrócenie stanu pierwotnego, zwłaszcza w przypadku skarp i dna rzeki

Pokrycie strat w przypadku ich wystąpienia oraz usunięcie szkód spowodowanych wykonaniem robót, na które wydano pozwolenie

Rys. 4. Wytyczne zawarte w pozwoleniu wodnoprawnym na przebudowę mostu Źródło: opracowanie własne na podstawie informacji o inwestycji.

Wykonanie zabezpieczeń brzegów materacami brzegowymi oraz skarp stożków dyblami z betonu ma za zadanie wzmocnić brzegi koryta narażone na erozję spowodowaną przepływem wody. Lokalizacja zaplecza budowy w oddaleniu od 
rzeki wynika z możliwości skażenia środowiska wodnego substancjami zawartymi w materiałach budowlanych oraz wyciekających ze stacjonujących na nim maszyn budowlanych. Zalecenie oczyszczania ścieków drogowych wskazuje na obowiązek wprowadzania do rzeki wyłącznie wody pozbawionej szkodliwych substancji. Natomiast uporządkowanie terenu po zakończeniu budowy i pokrycie wszelkich strat z niej wynikających jest elementem doprowadzenia obszaru do stanu pierwotnego w celu zachowania ładu przestrzennego, estetyki krajobrazu oraz naturalnego otoczenia inwestycji z okresu przed rozpoczęciem prac budowlanych.

Inwestycja 2 jest związana z odprowadzaniem oczyszczonych wód opadowych ze szczelnej powierzchni mostu do naturalnego odbiornika, jakim jest rzeka. Most ten zlokalizowany jest w ciągu drogi wojewódzkiej. W rozumieniu Prawa wodnego wylot kanalizacji deszczowej jest urządzeniem wodnym, dlatego możliwość odprowadzania wód opadowych i roztopowych musi być poparta wydaniem pozwolenia wodnoprawnego. W omawianym przypadku podmiotem ubiegającym się o uzyskanie pozwolenia wodnoprawnego jest Zarząd Dróg Wojewódzkich. Na jego zlecenie jedna $\mathrm{z}$ lokalnych firm sporządziła operat wodnoprawny w celu skompletowania informacji dotyczących gospodarki ściekowej i przeprowadzenia analizy jej stanu.

Zgodnie z przepisami do obowiązków inwestora poza wybudowaniem urządzeń należy utrzymanie systemu kanalizacyjnego mostu w dobrym stanie technicznym i eksploatacyjnym. Eksploatacja powinna odbywać się zgodnie z zaleceniami opisanymi w instrukcji obsługi i konserwacji urządzeń oczyszczających, a wszelkie czynności z nią związane muszą być zanotowane w zeszycie eksploatacji. Przegląd urządzeń oczyszczających powinien odbywać się dwa razy do roku, a na bieżąco należy kontrolować napełnienie studni zawiesiną i usuwać zalegające we wpustach mostowych liście, gałęzie i inne zanieczyszczenia.

Istotne jest także usuwanie zgromadzonego szlamu ze studni nie rzadziej niż co trzy miesiące oraz konserwacja wylotu ścieków. W przypadku separatora zintegrowanego z osadnikiem niezbędne jest utrzymanie ich sprawności technicznej, ponieważ stanowią najważniejszy punkt systemu oczyszczającego ścieki opadowe. Wszelkie odstępstwa od ustaleń zawartych w operacie i pozwoleniu odnoszące się do funkcjonowania kanalizacji deszczowej muszą być zgłaszane organowi wydającemu pozwolenie wodnoprawne. Daje się zauważyć, że w tym przypadku wytyczne zostały zdominowane przez zalecenia eksploatacyjne, a pominięto zalecenia dotyczące realizacji robót. Obowiązki te zestawiono w diagramie na rys. 5. 

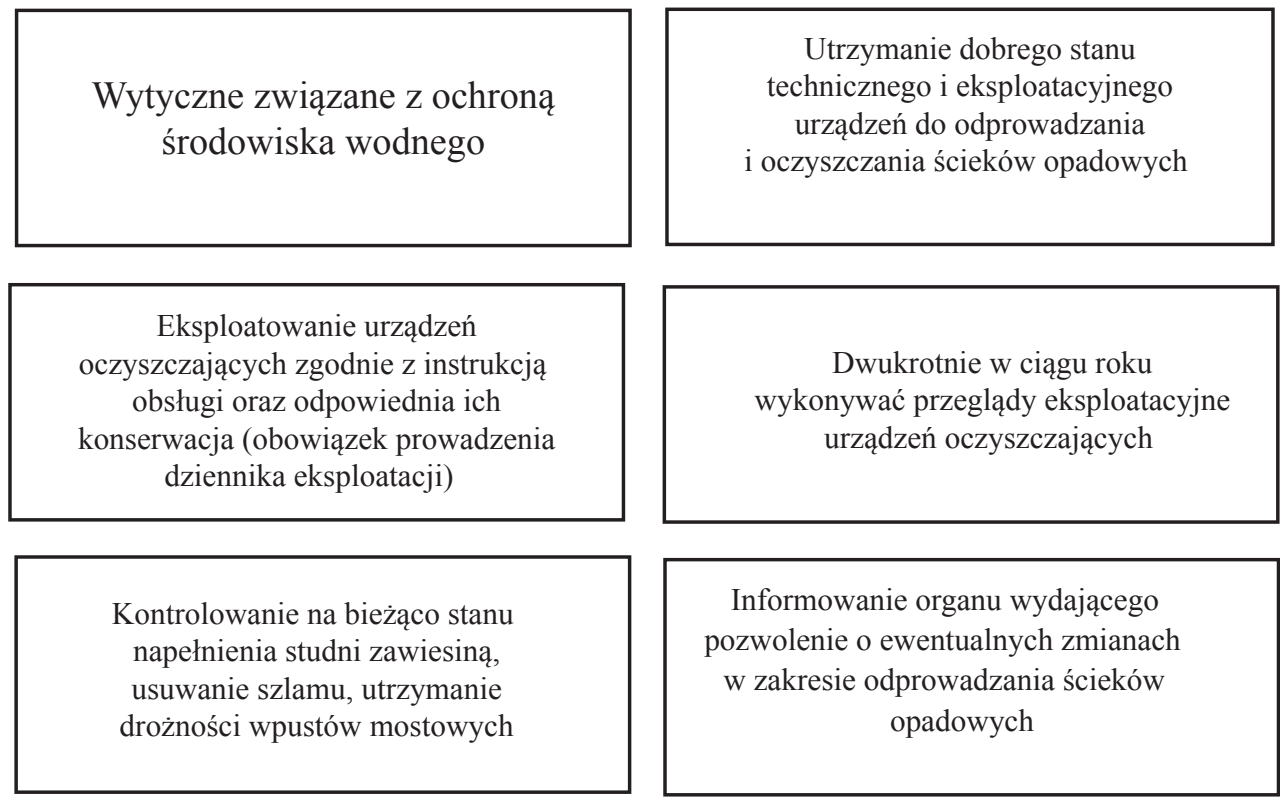

Informowanie organu wydającego pozwolenie o ewentualnych zmianach w zakresie odprowadzania ścieków opadowych

Utrzymanie separatora oraz sieci kanalizacji deszczowej

w odpowiednim stanie technicznym i zapewnienie sprawności ich działania

Rys. 5. Wytyczne zawarte w pozwoleniu wodnoprawnym na odwodnienie mostu

Źródło: opracowanie własne na postawie uzyskanych informacji o inwestycji.

Inwestycja 3 to przebudowa drogi wraz z odwodnieniem. Wniosek o wydanie pozwolenia obejmuje zbiorcze wykonanie kilku prac będących składowymi jednego procesu inwestycyjnego. Operat wodnoprawny, który był podstawą do wydania pozwolenia wodnoprawnego, dostarczył informacji o rozwiązaniach, jakie należy przyjąć, aby to przedsięwzięcie było zgodne z prawem wodnym. Po przeanalizowaniu operatu wodnoprawnego do projektu przebudowy drogi starosta udzielił pozwolenia wodnoprawnego na wykonanie wymienionych urządzeń wodnych na okres 10 lat. W trosce o bezpieczeństwo środowiska wodnego, na które będzie oddziaływać planowane przedsięwzięcie, na inwestora zostało nałożone kilka obowiązków. Pokazano je na rys.6. 

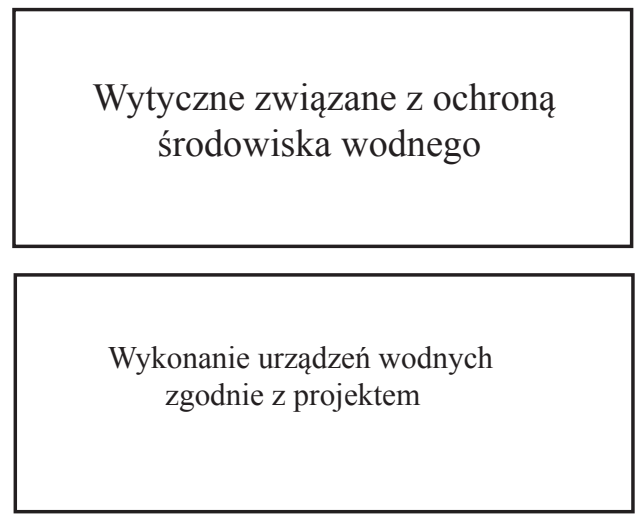

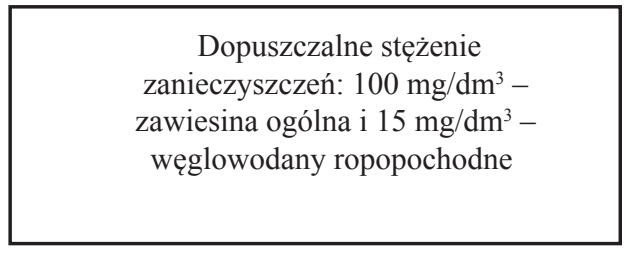

Pokrycie strat w przypadku ich wystąpieniaorazusunięcie szkód spowodowanych wykonaniem robót, na które wydano pozwolenie

Utrzymanie urządzeń wodnych w odpowiednim stanie technicznym zapewniającym jego prawidłowe funkcjonowanie

Rys. 6. Wytyczne w pozwoleniu wodnoprawnym na przebudowę odcinka drogi wojewódzkiej Źródło: opracowanie własne na podstawie uzyskanych informacji o inwestycji.

Operat wodnoprawny wskazał 14 rowów chłonnych i 6 rowów odwadniających, w które według projektu jest wyposażona droga. Rowy odwadniające gromadzą wodę opadową z prawego pasa ruchu, poboczy oraz zjazdów do posesji, a następnie odprowadzają ją do rowów chłonnych skąd przenika ona do gruntu. Ze względu na to w wytycznych określono dopuszczalne stężenie zanieczyszczeń. Rowy wykazują dość wysoki stopień redukcji zanieczyszczeń, który w przypadku oczyszczania wód opadowych pochodzących z omawianego odcinka jest wystarczający. Prawidłowe funkcjonowanie takiego rodzaju systemu odwodnienia uzależnione jest od wykonania ich zgodnie z projektem oraz od odpowiedniej konserwacji urządzeń. Do wszelkich prac konserwacyjnych jest zobowiązany właściciel drogi. Podobnie jak w przypadku pierwszej inwestycji uporządkowanie terenu po zakończeniu budowy i pokrycie wszelkich strat z niej wynikających jest elementem doprowadzenia obszaru do stanu z okresu przed rozpoczęciem prac budowlanych.

\section{Podsumowanie i wnioski}

Inwestycje drogowe zalicza się do przedsięwzięć mogących zawsze lub znacznie oddziaływać na środowisko. W związku z tym powstały przepisy, które mają na celu ograniczenie wpływu szkodliwych zjawisk wynikających z budowy oraz eksploatacji dróg. Podstawowym aktem prawnym w dziedzinie ochrony wód jest prawo 
wodne. Na jego mocy inwestor zobowiązany jest do złożenia wniosku o uzyskanie pozwolenia wodnoprawnego, gdy inwestycja drogowa może oddziaływać znacznie na środowisko wodne. Organ odpowiedzialny za wydanie tej decyzji opiera się na analizie operatu wodnoprawnego. W przypadku udzielenia pozwolenia wodnoprawnego na wykonanie inwestycji drogowej inwestor jest zobowiązany do zrealizowania przedsięwzięcia zgodnie z zawartymi w nim wytycznymi.

Porównanie liczby wytycznych zawartych w procedurach i dokumentacji związanej z uzyskaniem decyzji wodnoprawnej trzech przykładowych inwestycji przedstawione w tab. 1 pokazuje, że najważniejszym zadaniem inwestora jest zabezpieczenie wód przed zanieczyszczeniem ich substancjami spływającymi z nawierzchni dróg.

Tabela 1. Zestawienie wytycznych zawartych w pozwoleniach wodnoprawnych dla analizowanych inwestycji

\begin{tabular}{|l|c|c|c|}
\hline \multicolumn{1}{|c|}{ Wytyczne/ inwestycje } & Inwestycja 1 & Inwestycja 2 & Inwestycja 3 \\
\hline Liczba wytycznych ogółem & 5 & 7 & 4 \\
\hline $\begin{array}{l}\text { Liczba wytycznych związanych } \\
\text { z odprowadzeniem wód }\end{array}$ & 2 & 7 & 3 \\
\hline $\begin{array}{l}\text { Liczba wytycznych związanych } \\
\text { z realizacją i zakończeniem robót }\end{array}$ & 3 & - & 2 \\
\hline $\begin{array}{l}\text { Liczba wytycznych związanych } \\
\text { z okresem eksploatacji }\end{array}$ & 2 & 7 & 2 \\
\hline
\end{tabular}

Źródło: opracowanie własne na podstawie przeprowadzonej analizy.

Wytyczne dotyczą zarówno okresu realizacji robót, momentu ich zakończenia, oddania urządzeń do użytku jak i okresu eksploatacji. W każdej analizowanej inwestycji pojawiają się wytyczne dotyczące zabezpieczenia wód, a największy nacisk na ten problem położono przy budowie odprowadzenia deszczówki z przebudowywanego mostu. Wynika to z bezpośredniego zagrożenia dla stanu wód w przepływającej pod mostem rzece.

Analizując procedury zapewniające ochronę środowiska wodnego przy realizacji inwestycji drogowych, możemy zauważyć, że prawodawca zadbał o zabezpieczenie środowiska wodnego na wszystkich etapach procesu inwestycyjnego.

\section{Literatura}

Bęben D., 2009, Ochrona środowiska w budownictwie komunikacyjnym, Wydawnictwo Politechniki Opolskiej, Opole.

Dyrektywa 2000/60/WE Parlamentu Europejskiego i Rady z dnia 23 października 2000 r. ustanawiająca ramy wspólnotowego działania w dziedzinie polityki wodnej, Dz.U. UE L z 22 grudnia $2000 \mathrm{r}$.

Edel R., 2010, Odwodnienie dróg, Wydawnictwo Komunikacji i Łączności, Warszawa. 
Kot M., 2012, Wybrane problemy zwiazane z przygotowaniem inwestycji drogowych $w$ aspekcie prawa wodnego i ochrony środowiska, Regionalny Zarząd Gospodarki Wodnej w Krakowie, Kraków.

Koza I. (red.), 2002, Nowe prawo wodne, Zachodnie Centrum Organizacji, Zielona Góra.

Ociepa E., 2011, Ocena zanieczyszczenia ścieków deszczowych trafiających do systemów kanalizacyjnych, Inżynieria i Ochrona Środowiska, nr 4, t. 14, s. 357-364.

Rozporządzenie Ministra Transportu i Gospodarki Morskiej z dnia 2 marca 1999 r. w sprawie warunków technicznych, jakim powinny odpowiadać drogi publiczne i ich usytuowanie, Dz.U. 1999 nr 43, poz. 430.

Rozporządzenie Ministra Transportu i Gospodarki Morskiej z dnia 30 maja 2000 r. w sprawie warunków technicznych, jakim powinny odpowiadać drogowe obiekty inżynierskie i ich usytuowanie, Dz.U. $2000 \mathrm{nr}$ 63, poz. 735.

Sandecki T., 2002. Komentarz do warunków technicznych, jakim powinny odpowiadać drogi publiczne i ich usytuowanie. Część II: zagadnienia techniczne, Transprojekt, Warszawa.

Szafranko E., 2010, Procedura zwiazana z przygotowaniem inwestycji drogowej w świetle specustawy, Czasopismo Techniczne. Budownictwo, R. 107, z. 1-B, s. 405-417.

Szafranko E., 2013, Drogi a ekologia, Magazyn Autostrady, nr 8-9/2013, s. 22-27.

Ustawa z dnia 7 lipca 1994 r. - Prawo budowlane, Dz.U. 2010 nr 243, poz. 1623.

Ustawa z dnia 10 kwietnia 2003 r. o szczególnych zasadach przygotowania i realizacji inwestycji w zakresie dróg publicznych, Dz.U. 2003 nr 80, poz. 721.

Ustawa z dnia 18 lipca 2001 r. - Prawo wodne, Dz.U. 2012, poz. 145.

Ustawa z dnia 21 marca 1985 r. o drogach publicznych, Dz.U. $1985 \mathrm{nr}$ 14, poz. 60.

Ustawa z dnia 27 kwietnia 2001 r. - Prawo ochrony środowiska, Dz.U. 2001 nr 62, poz. 627.

Wiśniowska-Kielian B., Niemiec M., Arasimowicz M., 2013, Przydrożne zbiorniki ścieków opadowych jako element ochrony jakości wód, Inżynieria Ekologiczna, nr 34, s. 62-75. 